\title{
Environmental laws face military manoeuvres
}

\section{Mark Schrope}

The US military is mounting an offensive this year against an enemy within: the environmental regulation that, the Pentagon argues, constrains its training and affects military readiness.

The armed forces and their allies in Congress are all pushing for more exemption from environmental laws, arguing that some of them damage national security.

Ecologists and marine biologists, together with environmental groups, regard the laws as important tools in conserving the ecosystems on large tracts of land owned by the military, and in protecting marine wildlife from damage caused by war games. And although the Pentagon is yet to endorse any legal changes, it may be looking to the conservative administration of George W. Bush to create exemptions from laws such as the Endangered Species Act and the Marine Mammal Protection Act.

Last month, in a bid to expose this intention, an environmental group leaked a draft of a Navy document outlining problems that stem from environmental laws. The document, which has been in development since last December, describes problems such as the Navy's continuing struggle to test a sonar that might harm marine mammals (see Nature 410, 505; 2001), and lists ambiguities in current laws and their enforcement. It calls for more clarity in environmental laws, and for the collation and publication of data on their financial and operational impacts.

"This is what we would expect to see from the Bush administration in its attempts to roll back the environmental gains of the past 10 years," says Dan Meyer, a former Navy lieutenant and now a lawyer at Public Employees for Environmental Responsibility, the Washington-based lobby group that released the document.

Doug Spencer, a spokesman for the Navy, says: "The military is not out to damage the environment." He adds that it is against Navy policy to discuss working drafts, but that a

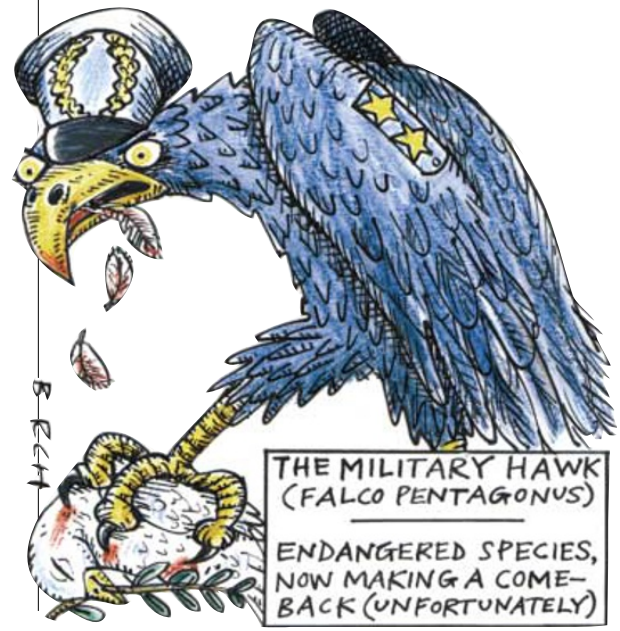

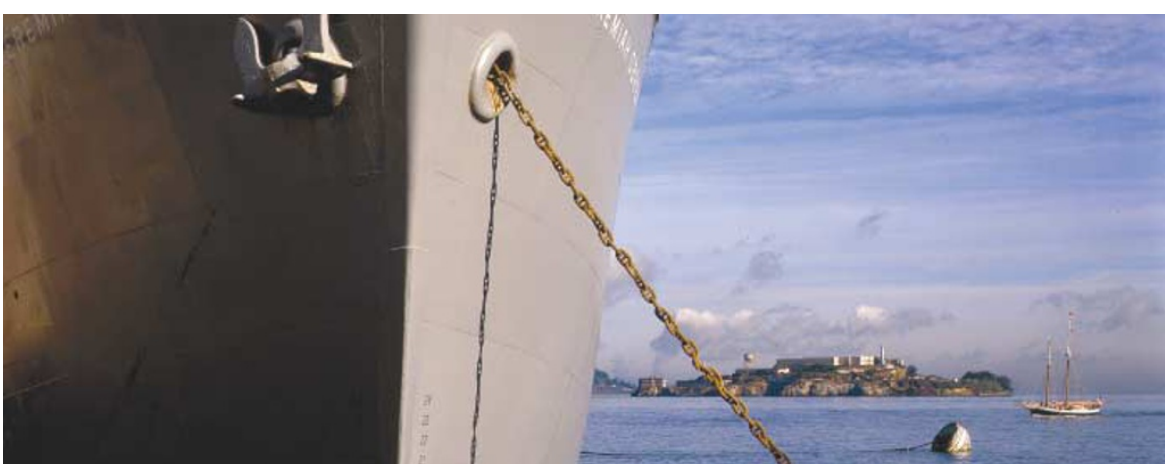

Legal anchor: a leaked Navy document outlined problems linked to US environmental regulations.

final version of the paper is now complete and will shortly be sent to Congress.

At a hearing of a House Armed Services subcommittee earlier this year, Joseph Angello, a senior Pentagon official, said that unrealistic combat training had "cost us lives and equipment" during real wars, such as the recent conflict in Kosovo. He argued that environmental rules restrict military exercises, causing "a slow degradation in our ability to test and train effectively". He also noted the irony that restrictions on base activities have increased as a result of the military's success in managing these areas - to the extent that some bases have become critical havens for endangered species.

The House of Representatives is consid-

ering a law that asks the Department of Defense to conduct national-security assessments on proposed operations, to accompany the environmental-impact assessments that are already required. Spencer says this would give a more balanced view of potential conflicts. "We have to look at the risks to national security," he says.

James MacMahon, an ecologist at Utah State University and former president of the Ecological Society of America, says he can imagine few situations in which the military would be unable to achieve a given goal without affecting endangered species. Any exemptions should be based on a nationalsecurity assessment of the potential number of lives the activity could save, he suggests.

\section{Listing resumes for species at risk}

\section{Mark Schrope}

The listing of endangered species of plants and animals in the United States is to be revived, following an agreement between the government and environmental groups.

For the past year, most of the government's budget for listing newly endangered species has been used to fight litigation from environmental groups aimed at forcing it to designate habitat needed for the recovery of species already listed.

In October 2000 the US Fish and Wildlife Service said that such legal work would probably consume its entire \$6-million listing budget for 2001, leaving nothing for the field assessment and listing of new species. Since then, only a few new species have been listed, mostly in response to court orders or to prevent litigation.

Faced with this, several environmental groups that were suing the service have been negotiating with it instead. Under an agreement announced on 29 August, the groups will allow the government more time to comply with court orders requiring it to designate habitat for eight protected species.
The government will in turn expedite the listing process for 29 of the more than 200 species under consideration.

The 29 include three species whose protection is considered an emergency, such as the pygmy rabbit, Brachylagus idahoensis, in Washington state, which has a population of less than 50. "It's a common-sense solution to the bad situation we found ourselves in this year," says Gary Frazer, assistant director for endangered species with the service.

Species were chosen according to such factors as their degree of risk and whether necessary protection measures are known, according to Kieran Suckling, head of the Center for Biological Diversity, based in Tucson, Arizona, one of the groups involved.

"We're biting off the tiniest tip of the iceberg," says Suckling. "To address the problem adequately, the Fish and Wildlife Service has to have a budget that is up to the task." The proposed budget for 2002 includes $\$ 8.5$ million for listing species, although the service's officials say it needs $\$ 120$ million to meet all of its legal liabilities under the endangered species act. 